\title{
Causes for the Rude Behavior of Elephants in and around the Udawalawe National Park
}

\author{
I. Ariff \\ Department of Geography, University of Peradeniya, Sri Lanka \\ isthikar.irf@gmail.com
}

\begin{abstract}
Sri Lankan elephants (Elphahas maximus maximus) genetically highly migrating sub-species need more and free natural ways to move to find their seasonal ecological niche as natural way of life. As study area, Udawalawe National Park (UNP) is a major elephant range and elephants are considered as key stone species of the park. The objective of this study was to find the causes for the rude behavior of elephants at the UNP. The fieldwork was conducted in east, west and south of the park through observation and interviews with officers and local people in April and December 2014. Data analysis was carried out based on obtained qualitative and quantitative data.
\end{abstract}

The villagers trespass to the park and corridors for number of illegal activities and also to build fences and huts. Besides this, visitors throw stones, hoot vehicle hones and flash their cameras. Due to the above such human activities and with the attraction of fruits and vegetables around the park, at night around $7.00 \mathrm{pm}$ to 1.00 am they feed and trample outside the park especially in March and April. People light crackers, light fires, shout, make noises with tins and coconut shells and sometimes shoot the elephants to chase. With such repeated incidents, the elephants become rude.

According to the field study, out of nearly 325 to 400 elephants, three or four elephants throw long logs onto the electric wires and by connecting two wires together they defuse them. Some elephants also push and fell the posts on which the barbed wires are fixed. Another three elephants push the wire with their backs intermittently and then cross the fence. When the elephants find their habitats and corridors blocked by settlements, walls and cultivation, stubborn to change their route, they demolish the walls, eat the crops and trample them as they move on. If anybody happens to encounter the elephants in such a situation, they pitch violently to the ground and trample to death. Elephants have adopted this behavior as their self-defense mechanism because of unethical human practices in and around the park and elephant corridors.

Keywords: Rude behaviour, Elephant, Udawala National Park 